\title{
EFFECTS OF NITROGEN ON GROWTH, YIELD AND POSTHARVEST QUALITY OF SELECTED CAULIFLOWER (Brassica oleracea) VARIETIES
}

\author{
N.K. KC ${ }^{* 1}$, H.N. Giri ${ }^{2}$, M.D Sharma ${ }^{3}$ and K.M. Tripathi ${ }^{4}$ \\ Department of Horticulture, Agriculture and Forestry University, Chitwan Nepal
}

\begin{abstract}
Cauliflower (Brassica oleracea var. botrytis L.) is one of the most popular vegetable crops. An experiment was conducted to study the response of late season varieties of cauliflower to different sources of nitrogen on growth, yield and postharvest quality at Rampur, Chitwan, Nepal during October 2018 to March 2019. Four late season varieties of cauliflower viz. NS 106, Snow Moon, Yukon, and Candid Charm and three different sources of nitrogen viz. 100\% Nitrogen $(\mathrm{N})$ through Farm yard manure, $50 \% \mathrm{~N}$ through $\mathrm{FYM}$ and $50 \% \mathrm{~N}$ through urea, and $100 \% \mathrm{~N}$ through urea. The two-factor experiment was laid in RCBD with three replications and twelve treatment combinations. All the recorded growth, yield and postharvest quality parameters were significantly higher and statistically similar in NS 106 and Yukon and significantly lower in Candid Charm. Similarly, significantly higher plant height, canopy diameter, leaf number, curd height, economic yield and biological yield were recorded in $50 \% \mathrm{~N}$ through FYM and $50 \% \mathrm{~N}$ through urea. Significantly lower plant height, canopy diameter, leaf number, economic yield and biological yield, titrable acidity and significantly higher days to curd maturity, vitamin C and dry matter content of leaf and curd, and TSS content were recorded in $100 \% \mathrm{~N}$ through FYM. Results revealed that for higher and postharvest quality of cauliflower during late season at Rampur, Chitwan Yukon or NS 106 both varieties were superior along with $50 \% \mathrm{~N}$ through FYM and $50 \% \mathrm{~N}$ than those of the other varieties.
\end{abstract}

Keywords: Cauliflower, Farm yard manure, Nitrogen, Postharvest, Yield

\section{INTRODUCTION}

Cauliflower (Brassica oleracea L. var. botrytis L.) is one of the most important vegetables and has highest share (14.6\%) in the total vegetable crop production as well as highest share $(13 \%)$ in the total vegetable cultivated area of Nepal. It covers an area of 450 ha with a total production of $6719 \mathrm{t}$ and average yield of $14.93 \mathrm{t} / \mathrm{ha}$

\footnotetext{
* Corresponding Author: kcnirmalarku@gmail.com
} 
Chitwan (MoALD, 2019). Cauliflower productivity is highly influenced by the genetic characteristics of the cultivar, planting time, growing temperature and applied fertilizers used (Chatterjee and Mahanta, 2013). Farmers are always in search of suitable varieties with desirable traits for better productivity, quality and resistance to important insect pests and diseases (Poudel et al., 2018). The late season varieties of cauliflower from November to March have long duration for curd maturity, low yield and poor post-harvest quality due to increase in temperature. The shortcoming of our local varieties is long duration i.e. 120-140 days for its maturity (HRD, 2013). So, the farmers are facing problems of having unattractive curd, poor taste, and low yield during late winter season.

The productivity of late season cauliflower is not satisfactory in Nepal due to unavailability of appropriate variety, poor soil fertility and imbalanced fertilization (Dhakal et al., 2014). Integrated use of organic manures and inorganic fertilizers is very essential not only for obtaining higher yield and better quality but also to maintain soil health and sustainability for longer period (Mallareddy and Rani, 2007). Increase in the cost of chemical fertilizers particularly that of nitrogen, coupled with concerns about pollution have focused attention on the use of combined application of nutrients through organic and inorganic sources in crop production. FYM is a very good organic fertilizer and powerful growth promoter over the conventional composts and a protective farm input, which increases the physical, chemical and biological properties of soil. So, this study was carried out to find the effects of different sources of nitrogen on yield and quality of different late season varieties of cauliflower in Rampur.

\section{MATERIALS AND METHODS}

The experiment was conducted during the period from October 2018 to March 2019 at the Horticulture Farm of Agriculture and Forestry University Rampur, Chitwan Nepal. The altitude of the experimental site is about $256 \mathrm{~m}$ above mean sea level and geographically situated at $27^{\circ} 37^{\prime}$ to $27^{\circ} 46^{\prime}$ North latitude and $83^{\circ} 35^{\prime}$ to $84^{\circ} 48^{\prime}$ East longitude. The climate of the experimental site is humid subtropical. The soil of the experimental field was acidic in nature $\mathrm{pH}$ 5.4. Monthly average data were collected from National Maize Research Program (NMRP), Rampur, Chitwan from October 2018 to March 2019.

The two-factor experiment was laid out in RCBD with three replications. Individual experimental plot area was $3 \mathrm{~m} \times 2.5 \mathrm{~m}\left(7.5 \mathrm{~m}^{2}\right)$, which comprised 25 plants. Spacing i.e., row to row distance of the cauliflower was $50 \mathrm{~cm}$ and plant to plant distance 60 $\mathrm{cm}$. There were total 900 plants including the border plants. Net experimental plot area was $270 \mathrm{~m}^{2}$ while gross plot area for experimental plot was $390.5 \mathrm{~m}^{2}$. Four late season varieties of cauliflower viz. NS 106, Snow Moon, Yukon, and Candid Charm and three different sources of nitrogen $100 \%$ Nitrogen $(\mathrm{N})$ through Farm yard manure, 50\% $\mathrm{N}$ through FYM and 50\% $\mathrm{N}$ through urea, and 100\% $\mathrm{N}$ through urea were used for this experiment. 
The recommended dose of NPK and FYM for cauliflower is 200:120:80 kg/ha and 30 ton/ha (Agriculture diary, 2075). The recommended amount of nitrogen was applied through three different sources i.e., $100 \% \mathrm{~N}$ through FYM $\left(\mathrm{N}_{1}-100 \% \mathrm{~N}-\mathrm{FYM}\right), 50 \%$ nitrogen through FYM and 50\% through urea $\left(\mathrm{N}_{2}-50 \% \mathrm{~N}-\mathrm{FYM}\right.$ and $50 \% \mathrm{~N}$-urea) and $100 \% \mathrm{~N}$ from urea $\left(\mathrm{N}_{3}-100 \% \mathrm{~N}\right.$ - urea). FYM sample was analyzed and $\mathrm{N}$ content was $(0.9 \%)$. The well decomposed FYM, whose nitrogen content was known, was applied double assuming that only $50 \%$ of $\mathrm{N}$ would be mineralized for the $\mathrm{N}$ availability in the first season according to the treatment just one week before transplanting of the seedlings. The observation was recorded at 25, 40, 55 days after transplanting (DAT) and harvesting day and then mean was calculated. Out of total requirement of nitrogen, nitrogen given through FYM was applied two weeks before transplanting of seedlings and nitrogen given through urea was applied in two split doses.

\section{Growth}

Plant height was measured from the ground level to the growing point. Stem diameter was measured with the help of Vernier's Calliper at harvesting day. Green, photosynthetically active leaves were considered as effective leaf number. Length of longest leaf in the plant was measured from the base of the leaf tip and width of the leaf was also measured. Diagonal length and width at top surface of the plant representing the plant coverage was measured from the selected five plants and the mean was calculated.

\section{Yield}

Days to curd initiation and days to curd maturity were recorded. Fresh weight of leaves and stem from five selected plants was recorded. The percent dry matter content was calculated by using following formula.

$$
\begin{gathered}
\mathrm{DM}=\frac{\mathrm{Ws}-\mathrm{Ds}}{\mathrm{Ws}} \times 100 \\
\text { Where, } \mathrm{DM}=\text { Dry matter }(\%) \\
\text { Ws }=\text { Curd sample }(\mathrm{gm}) \\
\text { Ds }=\text { Oven dry sample }(\mathrm{gm})
\end{gathered}
$$

Economic yield was considered as the total yield of the curd with inner 3-4 jacket leaves excluding the roots, stem and leaves immediately after the harvest. The total yield of curd along with roots and leaves immediately after harvest was recorded as the biological yield.

\section{Quality}

The physiological loss in weight of randomly selected five curds from each experimental plot was examined by keeping curds in room condition $\left(20 \pm 3{ }^{\circ} \mathrm{C}\right.$ and $60 \pm 5 \%$ ) for a week. The physiological loss in weight (PWL) was calculated using following formula: 


$$
\operatorname{PWL}(\%)=\frac{\text { Initial wt. of sample }- \text { Final wt. of sample }}{\text { Initial weight of sample }} \times 100
$$

Similarly, the spoilage loss was calculated to assess the keeping quality of the curd after harvest by using following formula:

$$
\text { Spoilage loss }(\%)=\frac{\text { Weight of spoiled curds }}{\text { Original weight of curds }} \times 100
$$

Total soluble solids (TSS) and $\mathrm{pH}$ of each sample was measured by hand refractometer (ERMA Inc., Tokyo, Japan) and digital $\mathrm{pH}$ meter, respectively. Vitamin $\mathrm{C}$ content of the ripe fruit was measured by volumetric method (Sadasivsm and Manickam, 1991).

Amount of ascorbic acid $(\mathrm{mg} / 100 \mathrm{~g}$ sample $)=\frac{0.5 \mathrm{mg} \times \mathrm{V} 2 \times 100 \times 100}{\mathrm{~V} 1 \mathrm{ml} \times 5 \mathrm{ml} \text { weight of the juice }}$

Where, $\mathrm{V}_{1}=$ amount of dye consumed during the titration

$4 \%$ oxalic acid

$\mathrm{V}_{2}=$ amount of dye consumed when the supernatant was titrated with

Percent titratable acidity was calculated by using the following formula.

Titrable acidity $(\%)=\frac{\mathrm{ml} \text { of } \mathrm{NaOH} \text { used } * \text { acid factor } *}{\mathrm{ml} \text { of juice taken }} 100$

\section{Statistical analysis}

Data were systematically arranged on Microsoft Excel and GenStat and analysis of variance was calculated along with other analysis. Means were compared using Duncan's Multiple Range Test (DMRT) at 0.05 and 0.01 levels of significance.

\section{RESULTS AND DISCUSSION}

\section{Response of late season varieties of cauliflower and different sources of nitrogen on growth}

Plant height, leaf length, leaf breadth, leaf number and canopy diameter were significantly influenced by different late season varieties of cauliflower and source of nitrogen at different stages of growth (Table 1 and 2). Statistically higher plant height, leaf length and breadth were found in NS 106 and Yukon, whereas the lower plant height, leaf length and breadth, canopy diameter and number of leaves were recorded in Candid Charm. The results of this study are similar to the results of Maurya et al. (2008), who reported a greater number of leaves from combined application of FYM and inorganic fertilizer than inorganic fertilizer alone in broccoli. 
Significantly higher plant height, leaf length and breadth, canopy diameter and number of leaves per plant were recorded in nitrogen provided through $50 \% \mathrm{~N}$-Urea and $50 \%$-FYM which might be due to readily available nutrients from urea at early stage while at the later stage of growth it might be due to continuous supply of nutrients for longer period to the plant from FYM.

Table 1. Plant height, leaf length, leaf breadth as influenced by late season varieties of cauliflower and different sources of nitrogen at Rampur, Chitwan 2018/19

\begin{tabular}{|c|c|c|c|c|c|c|c|c|c|c|c|c|}
\hline \multirow{2}{*}{$\begin{array}{l}\text { Treatments } \\
\text { Factor A } \\
\text { (Varieties) }\end{array}$} & \multicolumn{2}{|c|}{25 DAT } & \multirow[b]{2}{*}{ LB } & \multicolumn{2}{|c|}{40 DAT } & \multirow[b]{2}{*}{ LB } & \multicolumn{2}{|c|}{$55 \mathrm{DAT}$} & \multicolumn{4}{|c|}{ Final Harvest } \\
\hline & A: $\mathrm{PH}$ & LL & & $\mathrm{PH}$ & LL & & PH & LL & LB & $\mathrm{PH}$ & LL & LB \\
\hline NS 106 & $26.47^{\mathrm{a}}$ & $22.22^{\mathrm{ab}}$ & $11.16^{\mathrm{ab}}$ & $47.67^{\mathrm{a}}$ & $43.42^{\mathrm{a}}$ & $22.11^{\mathrm{a}}$ & $59.87^{\mathrm{a}}$ & $56.06^{\mathrm{a}}$ & $28.01^{\mathrm{a}}$ & $69.91^{\mathrm{a}}$ & $64.29^{\mathrm{a}}$ & $30.46^{\mathrm{a}}$ \\
\hline Snow Moon & $23.44^{\mathrm{b}}$ & $19.90^{c}$ & $10.54^{\mathrm{bc}}$ & $39.73^{\mathrm{b}}$ & $39.03^{b}$ & $20.24^{\mathrm{b}}$ & $54.76^{\mathrm{b}}$ & $52.46^{\mathrm{b}}$ & $25.99^{\mathrm{b}}$ & $66.22^{\mathrm{b}}$ & $61.74^{\mathrm{b}}$ & $28.45^{\mathrm{b}}$ \\
\hline Yukon & $27.62^{\mathrm{a}}$ & $23.54^{\mathrm{a}}$ & $12.09^{\mathrm{a}}$ & $47.80^{\mathrm{a}}$ & $43.67^{\mathrm{a}}$ & $22.13^{\mathrm{a}}$ & $61.55^{\mathrm{a}}$ & $58.19^{\mathrm{a}}$ & $28.82^{\mathrm{a}}$ & $71.71^{\mathrm{a}}$ & $65.28^{\mathrm{a}}$ & $31.88^{\mathrm{a}}$ \\
\hline Candid Charm & $23.89^{b}$ & $20.42^{\mathrm{bc}}$ & $9.93^{\mathrm{c}}$ & $42.01^{\mathrm{b}}$ & $35^{\mathrm{c}}$ & $17.92^{\mathrm{c}}$ & $51.66^{\mathrm{c}}$ & $48.14^{\mathrm{c}}$ & $24.25^{\mathrm{c}}$ & $61.21^{\mathrm{c}}$ & $56.23^{\mathrm{c}}$ & $25.77^{\mathrm{c}}$ \\
\hline SEM & 0.84 & 0.88 & 0.52 & 1.41 & 1.42 & 0.76 & 1.25 & 1.26 & 0.83 & 1.38 & 1.2 & 0.85 \\
\hline $\mathrm{LSD}_{0.05}$ & 1.73 & 1.83 & 1.07 & 2.92 & 2.95 & 1.57 & 2.60 & 2.61 & 1.72 & 2.87 & 2.48 & 1.76 \\
\hline F-test & $* *$ & $*$ & $*$ & $* *$ & $* *$ & $* *$ & $* *$ & $* *$ & $* *$ & $* *$ & $* *$ & $* *$ \\
\hline \multicolumn{13}{|c|}{ Sources of nitrogen } \\
\hline $100 \%$ N-FYM & $24.22^{\mathrm{b}}$ & $21.72^{\mathrm{a}}$ & $10.07^{\mathrm{b}}$ & $42.23^{\mathrm{b}}$ & $37.27^{\mathrm{c}}$ & $18.29^{\mathrm{c}}$ & $52.35^{\mathrm{c}}$ & $48.77^{\mathrm{c}}$ & $23.19^{\mathrm{c}}$ & $59.57^{\mathrm{c}}$ & $54.70^{\mathrm{c}}$ & $24.27^{\mathrm{c}}$ \\
\hline $\begin{array}{l}50 \% \quad \text { N-urea } \\
\text { and } 50 \% \quad \text { N- } \\
\text { FYM }\end{array}$ & $26.01^{\mathrm{a}}$ & $21.89^{\mathrm{a}}$ & $11.38^{\mathrm{a}}$ & $44.92^{\mathrm{a}}$ & $43.47^{\mathrm{a}}$ & $22.53^{\mathrm{a}}$ & $60.61^{\mathrm{a}}$ & $57.50^{\mathrm{a}}$ & $30.49^{\mathrm{a}}$ & $73.07^{\mathrm{a}}$ & $67.58^{\mathrm{a}}$ & $33.37^{\mathrm{a}}$ \\
\hline $100 \% \mathrm{~N}$ - urea & $25.84^{\mathrm{a}}$ & $21.69^{\mathrm{a}}$ & $11.33^{\mathrm{a}}$ & $45.76^{\mathrm{a}}$ & $40.11^{\mathrm{b}}$ & $20.96^{\mathrm{b}}$ & $57.92^{\mathrm{b}}$ & $54.87^{\mathrm{b}}$ & $26.63^{\mathrm{b}}$ & $69.16^{\mathrm{b}}$ & $63.38^{\mathrm{b}}$ & $29.77^{b}$ \\
\hline SEM & 0.72 & 0.76 & 0.45 & 1.22 & 1.23 & 0.66 & 1.08 & 1.09 & 0.72 & 1.20 & 1.04 & 0.74 \\
\hline $\mathrm{LSD}_{0.05}$ & 1.50 & 1.58 & 0.96 & 2.53 & 2.55 & 1.36 & 2.25 & 2.26 & 1.49 & 2.49 & 2.15 & 1.53 \\
\hline F-test & $*$ & NS & $*$ & $*$ & $* *$ & $* *$ & $* *$ & $* *$ & $* *$ & $* *$ & $* *$ & $* *$ \\
\hline $\mathrm{CV}, \%$ & 7 & 8.4 & 10 & 6.7 & 7.5 & 7.8 & 4.7 & 5 & 6.6 & 4.4 & 3.9 & 6.2 \\
\hline Grand mean & 25.4 & 21.8 & 10.9 & 44.3 & 40.3 & 20.6 & 57 & 53.7 & 26.8 & 67.9 & 61.9 & 29.1 \\
\hline
\end{tabular}

$* \mathrm{PH}=$ plant height, $\mathrm{LL}=$ leaf length, $\mathrm{LB}=\mathrm{Leaf}$ breadth, 
Table 2. Canopy diameter, number of leaves as influenced by late season varieties of cauliflower and different sources of nitrogen at Rampur, Chitwan $2018 / 19$

\begin{tabular}{|c|c|c|c|c|c|c|c|c|}
\hline \multirow{2}{*}{$\begin{array}{l}\text { Treatments } \\
\text { FactorA: } \\
\text { (Varieties) }\end{array}$} & \multicolumn{2}{|c|}{$25 \mathrm{DAT}$} & \multicolumn{2}{|c|}{40 DAT } & \multicolumn{2}{|r|}{$55 \mathrm{DAT}$} & \multicolumn{2}{|c|}{ Final Harvest } \\
\hline & $\begin{array}{l}\text { Canopy } \\
\text { diameter }\end{array}$ & $\begin{array}{l}\text { Number } \\
\text { of leaves }\end{array}$ & $\begin{array}{l}\text { Canopy } \\
\text { dimeter }\end{array}$ & $\begin{array}{l}\text { Number } \\
\text { of leaves }\end{array}$ & $\begin{array}{l}\text { Canopy } \\
\text { diameter }\end{array}$ & $\begin{array}{l}\text { Number } \\
\text { of leaves }\end{array}$ & $\begin{array}{l}\text { Canopy } \\
\text { diameter }\end{array}$ & $\begin{array}{l}\text { Number } \\
\text { of leaves }\end{array}$ \\
\hline NS 106 & $29.37^{\mathrm{a}}$ & $7.69^{\mathrm{a}}$ & $57.12^{\mathrm{a}}$ & $10.78^{\mathrm{a}}$ & $62.25^{\mathrm{a}}$ & $14.67^{\mathrm{a}}$ & $71.73^{\mathrm{a}}$ & $12.80^{\mathrm{a}}$ \\
\hline Snow Moon & $26.57^{\mathrm{b}}$ & $6.97^{\mathrm{c}}$ & $50.61^{\mathrm{b}}$ & $9.49^{\mathrm{b}}$ & $57.95^{\mathrm{b}}$ & $13.38^{\mathrm{bc}}$ & $66.55^{\mathrm{b}}$ & $11.89^{\mathrm{b}}$ \\
\hline Yukon & $30.55^{\mathrm{a}}$ & $7.42^{\mathrm{ab}}$ & $56.93^{\mathrm{a}}$ & $11.04^{\mathrm{a}}$ & $62.39^{\mathrm{a}}$ & $14.47^{\mathrm{bc}}$ & $72.64^{\mathrm{a}}$ & $12.78^{\mathrm{a}}$ \\
\hline Candid Charm & $24.46^{\mathrm{b}}$ & $7.06^{\mathrm{c}}$ & $45.08^{\mathrm{b}}$ & $9.02^{\mathrm{b}}$ & $53.49^{\mathrm{c}}$ & $12.44^{\mathrm{c}}$ & $61.98^{\mathrm{c}}$ & $10.69^{c}$ \\
\hline SEM & 1.20 & 0.18 & 2.02 & 0.45 & 1.97 & 0.55 & 2.05 & 0.41 \\
\hline $\mathrm{LSD}_{0.05}$ & 2.50 & 0.38 & 4.20 & 0.81 & 4.08 & 1.14 & 4.26 & 0.85 \\
\hline F-test & $* *$ & $*$ & $* *$ & $* *$ & $* *$ & $* *$ & $* *$ & $* *$ \\
\hline \multicolumn{9}{|c|}{ Factor B: Sources of Nitrogen } \\
\hline $100 \%$ N-FYM & $26.07^{\mathrm{b}}$ & $7.83^{\mathrm{a}}$ & $48.36^{\mathrm{b}}$ & $8.88^{\mathrm{b}}$ & $53.37^{\mathrm{c}}$ & $12.92^{\mathrm{b}}$ & $60.92^{c}$ & $9.97^{\mathrm{b}}$ \\
\hline $\begin{array}{l}50 \% \mathrm{~N} \text {-urea and } \\
50 \% \mathrm{~N}-\mathrm{FYM}\end{array}$ & $28.51^{\mathrm{a}}$ & $7.28^{\mathrm{a}}$ & $56.70^{\mathrm{a}}$ & $10.83^{\mathrm{a}}$ & $63.82^{\mathrm{a}}$ & $14.18^{\mathrm{a}}$ & $75.64^{\mathrm{a}}$ & $13.15^{\mathrm{a}}$ \\
\hline $100 \% \mathrm{~N}$ - urea & $28.64^{\mathrm{a}}$ & $7.20^{\mathrm{a}}$ & $52.25^{\mathrm{b}}$ & $10.53^{\mathrm{a}}$ & $59.86^{\mathrm{b}}$ & $14.12^{\mathrm{a}}$ & $68.11^{\mathrm{b}}$ & $13^{\mathrm{a}}$ \\
\hline SEM & 1.04 & 0.16 & 1.75 & 0.39 & 1.70 & 0.48 & 1.78 & 0.35 \\
\hline $\mathrm{LSD}_{0.05}$ & 2.16 & 0.33 & 3.64 & 0.81 & 3.53 & 0.99 & 3.69 & 0.73 \\
\hline F-test & $*$ & NS & $* *$ & $* *$ & $* *$ & $* *$ & $* *$ & $* *$ \\
\hline $\mathrm{CV}, \%$ & 9.2 & 5.3 & 8.2 & 9.5 & 7.1 & 8.5 & 6.4 & 7.2 \\
\hline Grand mean & 27.74 & 7.3 & 52.44 & 10.1 & 59 & 13.37 & 68.2 & 12 \\
\hline
\end{tabular}

\section{Response of late season varieties of cauliflower and different sources of nitrogen on yield}

The shortest period for curd initiation (64.32 days) was observed in NS 106 while the longest period (75.25 days) was recorded in Candid Charm. Similarly, days to curd initiation were significantly longer (73.54 days) in $100 \% \mathrm{~N}$-urea which was statistically similar to 50\% N through FYM and 50\% N through urea. Significantly longer period (97 days) to curd maturity was observed in Candid Charm and it was statistically similar with Yukon. Significantly shorter period (84.62 days) to curd maturity was recorded in NS 106 and it was statistically similar with Snow Moon. Days to curd maturity were significantly longer (97.52 days) in $100 \% \mathrm{~N}$ through FYM. The highest curd diameter of $21.84 \mathrm{~cm}$ was recorded in NS 106, which was statistically similar to Yukon, and the lowest curd diameter of $16.77 \mathrm{~cm}$ was recorded in Candid Charm and $12.60 \mathrm{~cm}$ at harvest. Likewise, the highest curd height of 13.36 $\mathrm{cm}$ was recorded in NS106 while the lowest curd height of $9.41 \mathrm{~cm}$ was recorded in 
Candid Charm. Similarly, at harvest, the highest curd diameter of $21.86 \mathrm{~cm}$ and curd height of $12.78 \mathrm{~cm}$ were recorded in 50\% $\mathrm{N}$ through urea and 50\% $\mathrm{N}$ through FYM while the lowest curd diameter $(17.40 \mathrm{~cm})$ and curd height $(10.25 \mathrm{~cm})$ was recorded in $100 \% \mathrm{~N}$ through FYM. The highest leaf weight $(0.14 \mathrm{~kg})$ was from recorded in Yukon was statistically similar to Snow moon. The highest total leaf weight $(1.38 \mathrm{~kg})$ per plant was observed 50\% N-urea and 50\% N-FYM whereas similar effect on total leaf weight was obtained in $100 \% \mathrm{~N}$ through FYM and 100\% $\mathrm{N}$ through urea. This study is in supported by Chitrakar (2004), who found application of 50\% RDF and $50 \%$ FYM resulted early head initiation, early head maturity as compared to $100 \%$ RDF (100:50:50 kg NPK/ha).

Table 3. Curd initiation days, curd maturity days, curd diameter, curd height, total leaf weight as influenced by varieties and sources of nitrogen at Rampur, Chitwan 2018/19

\begin{tabular}{|c|c|c|c|c|c|}
\hline Treatments & $\begin{array}{l}\text { Curd } \\
\text { initiation } \\
\text { (days) }\end{array}$ & $\begin{array}{l}\text { Curd } \\
\text { maturity } \\
\text { (days) }\end{array}$ & $\begin{array}{l}\text { Curd } \\
\text { dimeter }(\mathrm{cm})\end{array}$ & $\begin{array}{l}\text { Curd } \\
\text { height }\end{array}$ & $\begin{array}{l}\text { Total leaf } \\
\text { weight }(\mathrm{Kg})\end{array}$ \\
\hline \multicolumn{6}{|c|}{ Factor A: Varieties } \\
\hline NS 106 & $64.32^{\mathrm{c}}$ & $84.62^{\mathrm{c}}$ & $21.84^{\mathrm{a}}$ & $13.36^{\mathrm{a}}$ & $1.181^{\mathrm{a}}$ \\
\hline Snow Moon & $67.86^{\mathrm{bc}}$ & $89.70^{\mathrm{bc}}$ & $18.90^{\mathrm{b}}$ & $11.16^{\mathrm{b}}$ & $1.056^{\mathrm{b}}$ \\
\hline Yukon & $71.12^{\mathrm{ab}}$ & $93.03^{\mathrm{ab}}$ & $20.91^{\mathrm{a}}$ & $12.68^{\mathrm{a}}$ & $1.20^{\mathrm{a}}$ \\
\hline Candid Charm & $75.25^{\mathrm{a}}$ & $97^{\mathrm{a}}$ & $16.77^{\mathrm{c}}$ & $9.26^{\mathrm{c}}$ & $0.90^{\mathrm{c}}$ \\
\hline SEM & 2.14 & 2.07 & 0.763 & 0.53 & 0.0555 \\
\hline $\mathrm{LSD}_{0.05}$ & 6.18 & 6.07 & 1.58 & 1.11 & 0.1150 \\
\hline F-test & $*$ & $* *$ & $* *$ & $* *$ & $* *$ \\
\hline \multicolumn{6}{|c|}{ Factor B: (Sources of nitrogen of nitrogen) } \\
\hline $100 \%$ N- FYM & $65.82^{\mathrm{b}}$ & $97.52^{\mathrm{a}}$ & $17.40^{\mathrm{c}}$ & $10.25^{\mathrm{c}}$ & $0.72^{\mathrm{c}}$ \\
\hline $\begin{array}{l}50 \% \mathrm{~N} \text {-urea and } \\
50 \% \mathrm{~N}-\mathrm{FYM}\end{array}$ & $69.55^{\mathrm{ab}}$ & $85.82^{b}$ & $21.86^{\mathrm{a}}$ & $12.78^{\mathrm{a}}$ & $1.38^{\mathrm{a}}$ \\
\hline $100 \%$ N-urea & $73.54^{\mathrm{a}}$ & $85.92^{\mathrm{b}}$ & $19.57^{\mathrm{b}}$ & $11.81^{\mathrm{b}}$ & $0.72^{\mathrm{c}}$ \\
\hline SEM & 1.5 & 1.79 & 0.66 & 0.48 & 0.0480 \\
\hline $\mathrm{LSD}_{0.05}$ & 5.44 & 5.26 & 1.370 & 0.99 & 0.0996 \\
\hline F-test & $*$ & $* *$ & $* *$ & $* *$ & $* *$ \\
\hline $\mathrm{CV} \%$ & 9.23 & 6.82 & 8.3 & 11.58 & 9.3 \\
\hline Grand mean & 69.63 & 91.08 & 19.61 & 9.8 & 1.084 \\
\hline
\end{tabular}


The highest dry matter of the curd (11.48\%) and leaf (15.53\%) was recorded in NS 106 and the lowest dry matter of the curd $(11.72 \%)$ and leaf $(8.7 \%)$ was observed in Candid Charm. The highest dry matter $(16.18 \%)$ of leaf was recorded in $100 \% \mathrm{~N}$ through FYM and lower (11.07\%) in 100\% N-urea. Similarly, the highest dry matter of curd (11.28\%) was recorded in 100\% N through FYM. Mamatha (2006) reported highest dry matter content in onion bulbs with application of organic FYM. The increased dry matter accumulation with organics was attributed to the appreciable magnesium content in them (Singh, 2007).

The highest economic yield (41t/ha) was recorded in Yukon which was statistically similar to NS 106 (39.92 t/ha). Likewise, the lowest economic yield (27.49 t/ha) was recorded in Candid Charm. The highest economic yield (40.51 t/ha) was obtained from 50\% $\mathrm{N}$ through urea and 50\% $\mathrm{N}$ through FYM and lower from 100\% $\mathrm{N}$ through FYM. The longest root length of $23.52 \mathrm{~cm}$ was recorded in Yukon which was statistically similar with NS 106 while significantly lower root length of $18 \mathrm{~cm}$ was recorded in Candid Charm. Similarly, the highest root weight $(0.072 \mathrm{~kg})$ and the longest root length $(25.66 \mathrm{~cm})$ was observed in nitrogen provided through $100 \% \mathrm{~N}$ through FYM. The lower yield with inorganic fertilizers alone could be due to reduction in adequate supply of mineral nutrients because of fixation. Kumar (2013) have reported that integration of organic and inorganic fertilizers application significantly increased the yield in broccoli over inorganic fertilizers alone. These results are in accordance with the findings of Singh (2002) in cabbage, Manivanan and Singh (2004) in broccoli.

\section{Response of late season varieties of cauliflower and different sources of nitrogen on postharvest quality}

NS 106 and Yukon gave the higher values of TA (0.29\%). Similarly, TA was found significantly higher in $100 \%$ through $\mathrm{N}$ urea $(0.30 \%)$ and lower in $100 \% \mathrm{~N}$ through FYM (0.23\%). NS 106 and Yukon provided values TSS (4.11 and $4.04{ }^{\circ}$ Brix), respectively. The highest $\mathrm{pH}$ was recorded in NS 106 and Yukon (7.01 and 6.96). TSS content was recorded highest in 100\% $\mathrm{N}$ through FYM. Vitamin C content was significantly higher $(56.46 \mathrm{mg} / 100)$ in NS 106 and $(57.16 \mathrm{mg} / 100)$ in $100 \% \mathrm{~N}$ through FYM and lower in 100\% $\mathrm{N}$ through urea (50.71). The highest vitamin $\mathrm{C}$ content with FYM could be due to the essential elements present in it which enhanced vitamin $\mathrm{C}$ synthesis. In case of organically managed soil, plants are generally exposed with comparatively lower amount of nitrogen and several plant nutrients are released slowly over time. Therefore, organic crop would be expected to maintain lower vitamin C and less protein as reported by Bahadur et al. (2003) in broccoli. 
Table 4. Dry matter percentage of leaf and curd, economic yield, biological yield, root length and root weight as influenced by cauliflower varieties and sources of nitrogen at Rampur, Chitwan 2018/19

\begin{tabular}{|c|c|c|c|c|c|c|}
\hline Treatments & $\begin{array}{c}\text { Dry } \\
\text { matter } \\
\% \text { of } \\
\text { leaf }\end{array}$ & $\begin{array}{c}\text { Dry } \\
\text { matter } \\
\% \text { of } \\
\text { curd }\end{array}$ & $\begin{array}{c}\text { Economic } \\
\text { yield (t/ha) }\end{array}$ & $\begin{array}{l}\text { Biological } \\
\text { yield (t/ha) }\end{array}$ & $\begin{array}{l}\text { Root } \\
\text { length } \\
(\mathrm{cm})\end{array}$ & $\begin{array}{l}\text { Root } \\
\text { weight } \\
(\mathrm{Kg})\end{array}$ \\
\hline \multicolumn{7}{|l|}{ Factor A: Varieties } \\
\hline NS 106 & $15.53^{\mathrm{a}}$ & $11.48^{\mathrm{a}}$ & $39.92^{\mathrm{a}}$ & $80.05^{\mathrm{a}}$ & $23.30^{\mathrm{a}}$ & $0.068^{\mathrm{a}}$ \\
\hline Snow Moon & $12.91^{\mathrm{bc}}$ & $7.78^{\mathrm{b}}$ & $32.38^{\mathrm{b}}$ & $70.67^{\mathrm{b}}$ & $20.62^{\mathrm{b}}$ & $0.056^{\mathrm{b}}$ \\
\hline Yukon & $14.44^{\mathrm{ab}}$ & $10.27^{\mathrm{ab}}$ & $41.00^{\mathrm{a}}$ & $82.91^{\mathrm{a}}$ & $23.52^{\mathrm{a}}$ & $0.069^{\mathrm{a}}$ \\
\hline Candid Charm & $11.72^{\mathrm{c}}$ & $8.70^{\mathrm{b}}$ & $27.49^{\mathrm{c}}$ & $60.53^{\mathrm{c}}$ & $18^{\mathrm{c}}$ & $0.049^{\mathrm{b}}$ \\
\hline SEM & 0.8 & 0.84 & 2.08 & 3.6 & 0.005 & 1.24 \\
\hline $\mathrm{LSD}_{0.05}$ & 2.4 & 2.4 & 4.31 & 7.48 & 2.56 & 0.012 \\
\hline F-test & $*$ & $*$ & $* *$ & $* *$ & $* *$ & $* *$ \\
\hline \multicolumn{7}{|c|}{ Factor B: (Sources of nitrogen) } \\
\hline $100 \%$ N- FYM & $16.18^{\mathrm{a}}$ & $11.28^{\mathrm{a}}$ & $29.26^{\mathrm{c}}$ & $60.27^{\mathrm{c}}$ & $16.86^{\mathrm{c}}$ & $0.052^{\mathrm{b}}$ \\
\hline $\begin{array}{c}50 \% \mathrm{~N} \text {-urea and } \\
50 \% \mathrm{~N}-\mathrm{FYM}\end{array}$ & $13.70^{\mathrm{b}}$ & $9.51^{\mathrm{ab}}$ & $40.51^{\mathrm{a}}$ & $83.96^{\mathrm{a}}$ & $25.66^{\mathrm{a}}$ & $0.727^{\mathrm{a}}$ \\
\hline $100 \% \mathrm{~N}$-urea & $11.07^{\mathrm{c}}$ & $7.79^{\mathrm{b}}$ & $35.82^{\mathrm{b}}$ & $76.39^{\mathrm{b}}$ & $21.57^{\mathrm{b}}$ & $0.573^{b}$ \\
\hline SEM & 0.70 & 0.72 & 1.80 & 3.12 & 1.24 & 0.005 \\
\hline $\mathrm{LSD}_{0.05}$ & 2.08 & 2.13 & 3.73 & 6.47 & 2.22 & 0.010 \\
\hline F-test & $* *$ & $* *$ & $* *$ & $* *$ & $* *$ & $* *$ \\
\hline $\mathrm{CV} \%$ & 18 & 26 & 12.5 & 5 & 12.3 & 0.061 \\
\hline Grand mean & 13.64 & 9.56 & 35.20 & 73.5 & 21.4 & 20.20 \\
\hline
\end{tabular}

Physiological weight loss of curds after 7 days of storage was recorded significantly higher (32.26\%) in Snow Moon and was statistically similar in NS 106 and Yukon. Moreover, PLW of curds after 7 days of storage was significantly higher $(27.67 \%)$ in $100 \% \mathrm{~N}$ through urea. Spoilage loss of curds after seven days of storage was recorded the significantly higher in Candid Charm (44.22\%) whereas lower and statistically similar spoilage loss was observed in NS 106 and Yukon. Moreover, spoilage loss of curds was recorded significantly higher in $100 \% \mathrm{~N}$ - urea $(43.33 \%)$. More physiological weight loss from $100 \%$ urea may be attributed to soft tissues with high moisture content which in turn renders cauliflower to higher storage loss in cauliflower (Srinivas, 1990). 
Table 5. Titrable acidity, Vitamin $\mathrm{C}$, TSS, $\mathrm{pH}$, physiological weight loss and spoilage loss as influenced by varieties and sources of nitrogen at Rampur, Chitwan 2018/19

\begin{tabular}{|c|c|c|c|c|c|c|}
\hline Treatments & TA $(\%)$ & \multicolumn{2}{|c|}{$\begin{array}{c}\text { Vitamin } \\
\mathrm{C}(\mathrm{mg} / 100)\end{array}$} & \multirow[t]{2}{*}{$\mathrm{pH}$} & \multirow[t]{2}{*}{$\begin{array}{c}\text { Physiological } \\
\text { weight loss (\%) }\end{array}$} & \multirow[t]{2}{*}{$\begin{array}{c}\text { Spoilage loss } \\
\%\end{array}$} \\
\hline \multicolumn{4}{|c|}{ Factor A: (Varieties) } & & & \\
\hline NS 106 & $0.29^{\mathrm{a}}$ & $56.46^{\mathrm{a}}$ & $4.11^{\mathrm{a}}$ & $7.01^{\mathrm{a}}$ & $26.28^{\mathrm{bc}}$ & $38.89^{\mathrm{bc}}$ \\
\hline Snow Moon & $0.25^{\mathrm{b}}$ & $51.63^{\mathrm{b}}$ & $3.44^{\mathrm{b}}$ & $6.35^{\mathrm{b}}$ & $32.26^{\mathrm{a}}$ & $41.56^{\mathrm{ab}}$ \\
\hline Yukon & $0.29^{\mathrm{a}}$ & $54.38^{\mathrm{ab}}$ & $4.04^{\mathrm{a}}$ & $6.96^{\mathrm{a}}$ & $29.15^{\mathrm{ab}}$ & $37^{\mathrm{c}}$ \\
\hline Candid Charm & $0.22^{\mathrm{c}}$ & $53.22 b^{c}$ & $3.12^{\mathrm{b}}$ & $6.46^{\mathrm{b}}$ & $23.67^{\mathrm{c}}$ & $44.22^{\mathrm{a}}$ \\
\hline SEM & 0.015 & 1.6 & 0.262 & 0.12 & 1.78 & 1.28 \\
\hline LSD0.05 & 0.031 & 3.32 & 0.543 & 0.248 & 5.22 & 3.78 \\
\hline F-test & $* *$ & $* *$ & $*$ & $* *$ & $*$ & $* *$ \\
\hline \multicolumn{7}{|c|}{ Factor B: (Sources of nitrogen) } \\
\hline $100 \%$ N-FYM & $0.23^{\mathrm{c}}$ & $57.16^{\mathrm{a}}$ & $4.21^{\mathrm{a}}$ & $6.65^{\mathrm{a}}$ & $27.67^{\mathrm{ab}}$ & $37.42^{\mathrm{b}}$ \\
\hline $\begin{array}{llr}50 \% & \mathrm{~N}- & \text { urea } \\
\text { and } 50 \% & \mathrm{~N}- \\
\text { FYM } & \end{array}$ & $0.26^{\mathrm{b}}$ & $55.22^{\mathrm{b}}$ & $3.70^{\mathrm{b}}$ & $6.91^{\mathrm{a}}$ & $24.81^{\mathrm{b}}$ & $40.17^{\mathrm{ab}}$ \\
\hline $100 \% \mathrm{~N}-$ urea & $0.30^{\mathrm{a}}$ & $51.57^{\mathrm{b}}$ & $3.12^{\mathrm{c}}$ & $6.52^{\mathrm{b}}$ & $30.97^{\mathrm{a}}$ & $43.67^{\mathrm{a}}$ \\
\hline SEM & 0.013 & 1.39 & 0.227 & 0.103 & 1.54 & 1.11 \\
\hline LSD0.05 & 0.027 & 2.88 & 0.47 & 0.215 & 4.52 & 3.26 \\
\hline F-test & $* *$ & $* *$ & $* *$ & $*$ & $*$ & $* *$ \\
\hline $\mathrm{CV}, \%$ & 12.3 & 6.3 & 15.1 & 3.8 & 19.20 & 9.53 \\
\hline Grand mean & 0.26 & 53.92 & 3.68 & 6.7 & 27.18 & 40.41 \\
\hline
\end{tabular}

\section{CONCLUSION}

From this study it is concluded that higher growth, yield and postharvest quality of late season cauliflower in Rampur Chitwan condition was found in NS106 and Yukon variety. Integration of organic manure (FYM) and inorganic source of nitrogen fertilizer (urea) in combination of 50\% FYM and 50\% urea performed the synergetic effect on better vegetative growth and higher yield with better postharvest quality of the cauliflower in Rampur, Chitwan condition.

\section{REFERENCES}

Agriculture Diary. (2019). Krishi Diary. Government of Nepal, Agriculture Information and Communication Centre.

Chatterjee, R. and Mahanta, S. (2013). Performance of off-season cauliflower (Brassica oleracea var. botrytis L.) under agro shade net as influenced by planting dates and nutrient source. Environment, 1(1): 56-62 
Dhakal, D., Shah, S.C., Gautam, D.M. and Yadav, R.N. (2014). Rupandehi District. Nepal Agriculture Research Journal, 9: 56-66.

Dhakal, N. (2019). Performance of different varieties of cauliflower (Brassica Oleracea Var. Botrytis) under different level of nitrogen application in ultisols of Lamjung Nepal. World Journal of Agriculture and Soil Science, 1(2): 1-4.

HRD. (2006). Annual report. Horticulture Research Division, Nepal Agricultural Research Council, Khumaltar, Lalitpur, Nepal.

Kumar, P., Nanwal, R.K., and Yadav, S.K. (2005). Integrated nutrient management in pearl millet (Pennisetum glaucum)-wheat (Triticum aestivum) cropping system. Indian Journal of Agricultural Science, 75(10): 640-643.

MoALD. (2019) Statistical information on Nepalese agriculture 2018/19. Government of Nepal, Ministry of Agriculture and Livestock Development. Planning Development and Coordination Division.

Mallareddy, K. and Rani, S.N. (2007). Effect of different organic manures and inorganic fertilizers on growth, yield and quality of carrot (Daucus carota L.), Department of Horticulture, Karnataka. Journal of Agricultural Sciences, 20(3): 686-688.

Singh, A., Bharati, R.C., Chandra, N. and Dimree, S. (2002). Integrated Nutrient Management System: Smart way to improve cane production from sugarcane ratoon. Journal of Agri Search, 2(4): 233-243.

Singh, G., Sarvanan, S., Kerketta, A. and Rajesh, J. (2006). Effect of organic manures and inorganic fertilizers on plant growth, yield and flower bud quality of Broccoli (Brassica oleracea var. Italica) cv- Green Magic. International Journal of Pure and Applied Bioscience, 6(5): 1338-1342.

Srinivasarao, C., Venkateswarlu, B., Lal, R., Singh, A.K., Kundu, S., Vittal, K.P.R. and Patel, M.M. (2014). Long-term manuring and fertilizer effects on depletion of soil organic carbon stocks under pearl millet-cluster bean-castor rotation in Western India. Land Degradation and Development, 25(2): 173-183. 